\title{
Evaluation of Wound Healing Activity of Methanolic Crude Extract and Solvent Fractions of the Leaves of Vernonia auriculifera Hiern (Asteraceae) in Mice
}

\author{
Mulatu Kotiso Lambebo (D) \\ Zemene Demelash Kifle (iD ${ }^{2}$ \\ Tiruzer Bekele Gurji ${ }^{3}$ \\ Jibril Seid Yesuf (iD ${ }^{2}$ \\ 'Department of Pharmacy, College of \\ Medicine and Health Sciences, Hawassa \\ University, Hawassa, Ethiopia; \\ ${ }^{2}$ Department of Pharmacology, School of \\ Pharmacy, College of Medicine and \\ Health Sciences, University of Gondar, \\ Gondar, Ethiopia; ${ }^{3}$ Department of \\ Pathology, School of Medicine, College of \\ Medicine and Health Sciences, University \\ of Gondar, Gondar, Ethiopia
}

Correspondence: Jibril Seid Yesuf Department of Pharmacology, School of Pharmacy, College of Medicine and Health Sciences, University of Gondar, P.O. Box: 196, Gondar, Ethiopia

Tel +25191201676I

Email nimt3579@gmail.com
Background: Medicinal plants play an important role in treating various diseases. Vernonia auriculifera Hiern is one of the medicinal plants used traditionally for the management of wounds. However, there were no scientific reports documented so far on the wound healing activities to substantiate the claim. Thus, the present study provides a scientific evaluation for the wound healing potential of the crude extract as well as solvent fractions of the leaves of Vernonia auriculifera Hiern.

Methods: Extraction was carried out by maceration using $80 \%$ methanol and part of the crude extract fractionated with chloroform, ethyl acetate, and aqueous solvents. Simple ointment bases were prepared using hard paraffin, cetostearyl alcohol, white soft paraffin and wool fat according to British Pharmacopoeia. Then, two types of ointment formulations were prepared from the extract, ie, $5 \% \mathrm{w} / \mathrm{w}$ and $10 \% \mathrm{w} / \mathrm{w}$. Mice and rats were employed for wound healing study and dermal toxicity test, respectively. Wound healing effects were evaluated by percent of wound contraction, period of epithelialization, tensile strength, and histological analysis as parameters in excision, incision, and burn wound models. Finally, the data were expressed as mean \pm SEM, and the results were analyzed using one-way ANOVA followed by post hoc Tukey-test.

Results: In the excision wound model, the $10 \% \mathrm{w} / \mathrm{w}$ crude extract ointment showed significant wound contraction $(P<0.001)$ from day 4 to day 18 as compared to the negative control. Both the 5\% w/w $(P<0.001)$ and $10 \% \mathrm{w} / \mathrm{w}(P<0.05)$ crude extract ointments have showed statistically significant difference in epithelialization period as compared to the negative control. Groups treated with the ethyl acetate and aqueous fractions ointments in incision wound model showed a statistically significant $(P<0.001)$ increase in tensile. The $10 \% \mathrm{w} / \mathrm{w}$ and $5 \% \mathrm{w} / \mathrm{w}$ ointments of the crude extract showed a significant $(P<0.001)$ increase in breaking strength compared to simple ointment and the untreated control groups. In burn wound model, significant reduction in epithelialization period was observed in $5 \% \mathrm{w} /$ $\mathrm{w}(P<0.05)$ and $10 \% \mathrm{w} / \mathrm{w}(P<0.001)$, and the percentage of wound contraction was significantly increased in most of post wounding days by $10 \% \mathrm{w} / \mathrm{w}(P<0.001)$ and $5 \% \mathrm{w} / \mathrm{w}$ $(P<0.05)$ crude extract ointments and compared to the negative control.

Conclusion: The crude, aqueous, and ethyl acetate fraction of Vernonia auriculifera leaves possess wound healing activities. This finding justifies the use of the leaves of this plant for wound healing as claimed in the traditional medicine literature.

Keywords: wound healing, Vernonia auriculifera Hiern, wound models, leaves, Ethiopia

\section{Introduction}

A wound is a disruption of cellular and anatomic continuity, with impairment of the tissue's protective or physiological functions, ${ }^{1}$ and it may be due to chemical, 
physical, thermal, microbial, or immunological injury to the tissue. ${ }^{2}$ Wound healing is a natural body reaction leading to the restoration of structural and functional integrity of injured tissues. ${ }^{3}$ It is a complex and dynamic process of replacing devitalized and missing cellular structures and tissue layers. ${ }^{4}$

Wound infections are common in developing countries, such as Sub-Saharan African and South Asian countries because of poor hygienic conditions, ${ }^{5}$ and about $1-2 \%$ of the population experiences a chronic wound during their lifetime. $^{6,7}$ It has been estimated that 14 million people suffer from wounds and burns annually with over $80 \%$ of these living in low and middle-income countries. ${ }^{8}$ According to the World Health Organization about 300,000 deaths worldwide each year are due to burns. ${ }^{9}$ In Ethiopia, Surgical site infections (SSIs) are the commonest nosocomial infections and responsible for considerable morbidity and mortality as well as increased hospitalizations and treatment cost related to surgical operations. $^{10}$ The prevalence of SSIs remains high among postoperative patients in Ethiopia. ${ }^{11}$

Many medicinal plants have been reported to show wound healing activity. ${ }^{1,12-16}$ Extensive investigation has been carried out in the field of wound healing management by medicinal plants. ${ }^{1,12-14,17}$ Many plants and various preparations thereof have been used traditionally concerning wound treatment, especially due to their immense potential to affect the wound healing process. ${ }^{18}$ To mention some, Vernonia amygdalina Del, ${ }^{19}$ Brucea antidysenterica J.F.Mill, ${ }^{20}$ Achyranthes aspera, ${ }^{21}$ Croton macrostachyus, ${ }^{22}$ Datura stramonium, ${ }^{23}$ Bersama abyssinica, ${ }^{24}$ Rumexa byssinicus, ${ }^{1}$ Cordial africana, ${ }^{25}$ Aloe spp, ${ }^{26}$ and many others.

The genus Vernonia (Asteraceae family) has more than 1000 species growing all over the world. ${ }^{27}$ It has a wide folkloric use against diverse diseases. More importantly, it has gained wide application in the management of wound, ${ }^{28-33}$ and other medicinal uses such as relieve of headache, ${ }^{34}$ antiplasmodial, ${ }^{35-39}$ antibacterial, $^{34,40,41}$ diarrheal disease, ${ }^{42-45}$ snake bite poison, ${ }^{46-49}$ cataract, $^{40,50}$ toothache, ${ }^{44}$ placenta removal, ${ }^{33,51,52}$ skin cut/infection, ${ }^{53-55}$ dermatitis, ${ }^{56}$ febrile convulsion, ${ }^{57}$ anti-trypanosomal, ${ }^{33}$ endo/ ectoparasite, ${ }^{58,59}$ cancer or tumour, ${ }^{60}$ and eye infection and warts. ${ }^{61}$ The volatile oil from the leaf, crude extracts, fractions, and isolated pure compounds were tested in vitro to evaluate antimicrobial activity. Fractions and isolated compounds exhibited reasonable antimicrobial activities. ${ }^{62}$ Repeated use of solvent extraction followed by Column Chromatography and Thin layer Chromatography, the leaf extract of compound which was characterized as (E)-methyl 11hydroxy-1-(4 amide using UV, FT-IR and NMR) spectral data and by comparing with literature reports. ${ }^{63}$

Despite many traditional claims on wound healing and in vitro studies are available for Vernonia auriculifera Hiern, ${ }^{62,64,65}$ there is no scientific study reported in vivo, so that result of this study might serve as baseline information for further investigations. Thus, the purpose of this study was to evaluate the wound healing activities of the crude extracts and solvent fractions of leaves of Vernonia auriculifera Hiern which can, in turn, provide a foundation for the identification of pharmacologically active compounds.

\section{Materials and Methods}

\section{Drugs and Chemicals}

Drugs, chemicals, and reagents that were used for the study include nitrofurazone skin ointment United States Pharmacopeia (USP) $0.2 \%$ (Shanghai General Pharmaceuticals Co., Ltd., China), silver sulfadiazine skin ointment USP 1\% (Galentic Pharma Pvt. Ltd., India), ketamine hydrochloride $50 \mathrm{mg} / \mathrm{mL}$ injection USP (Neon Laboratories Limited, India), diazepam $5 \mathrm{mg} / \mathrm{mL}$ injection (Mission Pharma, Denmark), hard paraffin (Lab Tech Chemicals), wool fat (Uni-Chem Chemical Reagents), cetostearyl alcohol (Blulux Laboratories, India), methanol (99.9\%) (Alpha Chemika, India), ethanol (70\%) (Harego Chemicals, Addis Ababa), Ethyl acetate (Nice Chemicals Pvt. Ltd., India), chloroform (BDH Chemicals Ltd., England), bees wax (Bo International, Delhi, India),10\% buffered formalin (Sigma Diagnostics ${ }^{\mathrm{TM}}$, Livonia), paraffin wax (Reliance Wax Co., Ltd. China), hematoxylin and eosin (Alpha Chemika Maharashtra, India), hydrochloric acid (Blulux Laboratories Pvt. Ltd., India), Sodium hydroxide (Blulux Laboratories Pvt. Ltd.,India), sulphuric acid (HiMedia Laboratories Pvt. Ltd., India), lead acetate (Guangdong Guanghua chemicals factories, China), ferric chloride (Blulux Laboratories Pvt. Ltd., India) and Wagner's reagent (Research-Lab, Fine Chem Industries, India).

\section{Collection, Authentication, and Preparation of Plant Material}

Fresh leaves of Vernonia auriculifera Hiern were collected on 27th January 2020 from Gondar town, located in 
Amhara National Regional State, Northwestern Ethiopia. The plant was identified and authenticated by Mr Abiyu Enyew (Botanist) and voucher specimen 001MKL/2020 was deposited for future reference at Herbarium in College of Natural and Computational Sciences, University of Gondar. The collected plant leaves were cleaned with tap water to remove surface pollutants and shade dried at room temperature. The dried leaves were ground to a coarse powder using mortar and pestle and then packed in an appropriate plastic bag and kept until extraction on 19th February 2020.

\section{Experimental Animals}

Swiss albino mice of both sex (20-30g, and 8-10 weeks old) and female Wistar rats (Rattus norvegicus) weighing 150-200g, about 3-4 months old were obtained from the Department of Pharmacology, University of Gondar. The animals were housed in cages under standard conditions with 12 hours light and dark cycles. They were provided with a standard pellet diet and water ad libitum and acclimatized to the laboratory condition for a week before the starting of the experiment. They were handled according to international laboratory animal use and care guidelines throughout the experiment. ${ }^{66}$ At the end of the experiment, the animals were sacrificed on a high dose of ketamine and buried properly. The study was conducted after approval by the Postgraduate Committee of Department of Pharmacology, School of Pharmacy, and University of Gondar with a Reference number of SoP4/285/12.

\section{Extraction of Vernonia auriculifera Hiern}

The dried leaves of Vernonia auriculifera Hiern were coarsely powdered in a grinder and $880 \mathrm{~g}$ of the powder was cold macerated with $80 \%$ methanol in the ratio of $1: 6$ and then kept for three days at room temperature with occasional stirring and shaking. ${ }^{67}$ After $72 \mathrm{~h}$, the extract was separated from the marc using sterile gauze (cotton) and filtered further using Whatman filter paper No. 1. The residue was macerated further with $80 \%$ methanol for 72 h. This was repeated thrice to exhaust the extractable components. Then, the dried extract was kept separately in a desiccator until used for the experiment. ${ }^{68,69}$ The weight of the dry extract was expressed as a percentage of the total mass of dry plant powder to determine the percentage yield. ${ }^{70}$ For topical formulation and further fractionation, the dried extract was kept at a temperature of $-20{ }^{\circ} \mathrm{C} .{ }^{67}$

\section{Fractionation of Crude Extract}

The hydro-methanol crude extract was subjected to a successive extraction using a separatory funnel with chloroform, ethyl acetate, and distilled water. The dried crude extract of the leaves of Vernonia auriculifera Hiern was suspended in $450 \mathrm{~mL}$ of distilled water and slightly shaken to mix completely with solvent. The mixture was transferred into a separatory funnel. An equal volume of chloroform was added to it and the new mixture was shaken gently and allowed to settle till it formed two layers when the chloroform fraction was collected. The procedure was repeated twice to effectively isolate the chloroform fraction. An equal volume of ethyl acetate was added to the remaining aqueous portion in the separatory funnel and the solution was shaken. The ethyl acetate was separated from the aqueous portion and the procedure was repeated trice. The filtrate of chloroform and ethyl acetate fractions were dried by oven at $40{ }^{\circ} \mathrm{C}$ to obtain the respective fraction. The remaining aqueous residue was frozen in a deep freezer set at $-25{ }^{\circ} \mathrm{C}$ overnight and then freeze-dried with a lyophilizer to obtain an aqueous fraction. The percentage yield of the dried fractions was calculated and stored in a tight container in a refrigerator at $20{ }^{\circ} \mathrm{C}$ until used for the formulation of ointments. ${ }^{71}$

\section{Preliminary Phytochemical Screening}

Methanolic crude extract and solvent fractions of Vernonia auriculifera Hiern were subjected to various phytochemical screening tests to check the possible presence of secondary phytochemicals such as steroidal compounds, terpenes, tannins, alkaloids, flavonoids, saponins, and phenolic compounds in the leaves of the plant using standard procedures. $^{72-74}$

\section{Formulation of Ointment}

Simple ointment bases were prepared using hard paraffin, cetostearyl alcohol, white soft paraffin, and wool fat according to the British Pharmacopoeia. ${ }^{75,76}$ All the ingredients were melted together and stirred until it was cold. $^{77}$ Two types of ointment formulations were prepared from the extract: $5 \% \mathrm{w} / \mathrm{w}$ and $10 \% \mathrm{w} / \mathrm{w}$. To prepare the ointments, $5 \mathrm{~g}$ and $10 \mathrm{~g}$ of the powdered extract were incorporated into a portion of simple ointment base by levigating on the surface of the ointment slab to make an ointment of uniform consistency and smooth texture. The remainder of the simple ointment base was gradually added and mixed thoroughly. Finally, the ointment 
containing the extract was transferred to a clean container and labeled. The same procedure was adopted for the preparation of the ointments containing the respective fractions of the extract. Additionally, pre-formulated nitrofurazone ointment $(0.2 \% \mathrm{w} / \mathrm{w})$ was used as a standard drug for comparing the wound healing potential of the extract. ${ }^{78}$

\section{Wound Healing Models Grouping and Dosing of the Animals}

The mice were randomly grouped into four groups for excision, five groups for incision, and another four groups for burn wound (each 6 mice) for evaluation of crude extract wound healing activity. The mice in group I of all models were treated with simple ointment (hard paraffin, cetostearyl alcohol, white soft paraffin, and wool fat). Group II and III of all the models were given $5 \% \mathrm{w} / \mathrm{w}$ and $10 \% \mathrm{w} / \mathrm{w}$ crude extract ointments, respectively and the animals in group IV of all models except burn wound model were treated with nitrofurazone $0.2 \%$ ointment. For incision wound, group I-IV was treated as excision wound model described above but mice in group $\mathrm{V}$ was left untreated. Grouping of the mice in the burn model was similar to that of the excision model except for the positive control treated with silver sulfadiazine $(1 \% \mathrm{w} / \mathrm{w})$ cream.

The animals were randomly placed into various groups for the evaluation of solvent fractions based on the models. In the excision wound healing model, group I was treated with simple ointment (serving as a negative control); groups II and III were treated with $5 \% \mathrm{w} / \mathrm{w}$ and $10 \% \mathrm{w} /$ w chloroform ointment, respectively; groups IV and $\mathrm{V}$ were treated with $5 \% \mathrm{w} / \mathrm{w}$ and $10 \% \mathrm{w} / \mathrm{w}$ of ethyl acetate ointment, respectively; groups VI and VII were treated with $5 \% \mathrm{w} / \mathrm{w}$ and $10 \% \mathrm{w} / \mathrm{w}$ of aqueous ointment, respectively; group VIII was treated with $0.2 \% \mathrm{w} / \mathrm{w}$ nitrofurazone (serving as a positive control). In the incision wound model, the methods used in grouping and treating the animals as in the excision wound model were adopted except that an untreated group was added. The study was conducted by applying the extract and controls topically because the plant materials are traditionally used by local communities via an external route. The respective ointments were applied topically to the corresponding wounds once daily until complete healing was observed. The interventions were used topically since the plant materials have traditionally been used as such by the local communities. ${ }^{79}$

\section{Dermal Toxicity Testing}

The evaluation of dermal acute toxicity was carried out as per the Organization for Economic Cooperation and Development (OECD 434) guideline. ${ }^{80}$ Two groups of female rats (each containing five rats) showing normal skin texture were randomly selected and acclimatized to the laboratory condition for seven days before the test. Following acclimation, the rats were anesthetized by ketamine $80 \mathrm{mg} / \mathrm{kg}$ intraperitoneal injection, and around $10 \%$ of the body surface area fur was shaved $24 \mathrm{~h}$ before the study from the dorsal area of the trunk.

First, a sighting study was performed to allow the selection of the appropriate starting dose for the main study. The starting dose for the sighting study was selected from the fixed-dose levels. Hence, $1 \mathrm{~g} / \mathrm{kg}$ of $10 \%$ extract ointment was sequentially applied to a single rat. A period of $24 \mathrm{~h}$ was allowed between the testing of each animal. There was no death or skin irritation observed within 24 $h$. Therefore, four additional rats from each group were used for the main study, and a limit test dose of $2000 \mathrm{mg} /$ $\mathrm{kg}$ of the crude extract ointment formulation and simple ointment base was applied uniformly on the respective group. At the end of the exposure period, residual test substance was removed and the animals were observed for development of any adverse skin reactions especially for signs of erythema and edema, and the responses were scored at 24,48 , and $72 \mathrm{~h}$ after patch removal. Dermal reactions were graded, recorded and observation was continued daily for 14 days. ${ }^{80,81}$ The reactions were evaluated according to the scoring system for skin reactions. ${ }^{82}$ The score of primary irritation (SPI) was calculated for each rat as follows. Score for erythema and edema at 24, 48, and $72 \mathrm{~h}$ were summed and divided by the number of the observations for the treated groups. The SPI for the control groups were calculated in the same way as treated groups.

$$
\text { SPI for each rat }=\frac{\sum_{\text {grade at } 24,48 \text { and } 72 \mathrm{hrs}}^{\text {Erythema and Edema }}}{\text { Number of observations }}
$$

The difference between the summations of SPI scores of animals from each treated and control group was calculated and used for primary irritation index (PII) determination. The PII was calculated as the arithmetical mean of the SPI values of the rats. The irritation degree was categorized as negligible, or slight, moderate, or severe irritation based on the PII. 


$$
S P I I=\frac{\sum S P I(\text { test })-\sum S P I(\text { control })}{\text { No of animals }}
$$

\section{Excision Wound Healing Test}

An excision wound model was used to assess the wound healing activity of both crude and solvent extract of the leaves of Vernonia auriculifera in mice. The treatment was given based on the documented procedures. ${ }^{83-85}$

The mice were anesthetized using subcutaneous injection of ketamine $(80 \mathrm{mg} / \mathrm{kg})$ and diazepam $(5 \mathrm{mg} / \mathrm{kg})$ on wounding day. The back hair of the animals was removed by shaving. Ethanol $(70 \%)$ was used as an antiseptic for the shaved region before making the wound. ${ }^{86}$ About $300 \mathrm{~mm}^{2}$ circular areas were marked and the full thickness of the marked area was carefully excised by using sharp sterilized scissors and the inflicted wound was left undressed. After 24 hours of wound creation, the ointments were applied to their respective group gently once daily to cover the wounded area until complete healing was achieved. The mice were observed for wound closure and measurement was taken every two-post wounding days. Wound surface area was determined with Graph paper from which each square representing $1 \mathrm{~mm}^{2}$. Photographs were taken every two days to see wound contraction progress and then the wound healing activity of the crude extract was assessed by the period of epithelialization, percentage of wound contraction, and histological studies. By considering the initial size of the wound $300 \mathrm{~mm}^{2}$ as $100 \%$, the percentage of wound contraction was calculated as:

$$
\% \text { wound contraction }=\frac{\begin{array}{l}
\text { wound area in day } 0 \\
- \text { wound area in day } \mathrm{n} \times 100
\end{array}}{\text { Wound area in day } 0}
$$

Where $n=$ number of days ie $2 n d, 4$ th, 6 th, etc. until complete wound healing

Falling of scab or Escher leaving no raw wound behind were taken as an endpoint of complete epithelialization (a process by which keratinocytes, a major cellular component of the epidermis, are responsible for restoring the epidermis after injury), ${ }^{87}$ and the days required for this were taken as a period of epithelialization. ${ }^{88,89}$

\section{Incision Wound Healing Test}

In this case, wound was inflicted differently from that of excision wound. Here, the paravertebral incision $(3 \mathrm{~cm}$ long) was made through the full thickness of the skin on either side of the vertebral column at a distance of $1 \mathrm{~cm}$ from the midline. Non-absorbable surgical thread and a curved needle were used to stitch parted skin together at the intervals of $1 \mathrm{~cm}$. This wounding day was considered as day 0 and starting from day 1 , the first four groups were treated similarly as the groups in excision wound model and the fifth group served as untreated control. The treatments were topically applied once daily for 9 days. The sutures were removed on the 8th day of post wounding. Tensile strength was determined on day 10 . Two forceps were firmly applied $3 \mathrm{~mm}$ away from the edge of wound facing each other on the opposite side of the incision wound. One of the forceps was fixed on stands, while the other was connected to a freely suspended lightweight plastic of volume $1000 \mathrm{~mL}$ through a string run over to a pulley. Water was allowed to flow continuously from the reservoir slowly and steadily into the container. The moment the wound just opened up, the water flow was arrested and the volume of water collected in the container was noted as tensile strength. The breaking strength of the groups treated with extracts was compared with the nitrofurazone $0.2 \%$ ointment, simple ointment, and untreated control groups. ${ }^{89}$ The tensile strength was calculated as follows: $:^{1,90}$

$$
\begin{aligned}
\% \mathrm{TSe} & =\frac{\mathrm{TSe}-\mathrm{TSso}}{\mathrm{TSso}} \times 100 \\
\% \mathrm{TSr} & =\frac{\mathrm{TSr}-\mathrm{TSso}}{\mathrm{TSso}} \times 100 \\
\% \mathrm{TSso} & =\frac{\mathrm{TSso}-\mathrm{TSlu}}{\mathrm{TSlu}} \times 100
\end{aligned}
$$

Where, so=simple ointment, $\mathrm{TSr}=$ tensile strength of reference, and lu=left untreated

\section{Burn Wound Healing Test}

To test the burn wound, small healthy mice with the age of 6-8 weeks old were used. Initially, the mice were anesthetized through intraperitoneal injections of ketamine at a dose of $80 \mathrm{mg} / \mathrm{kg}$ of body weight then the hairs of the back region were removed. The shaved area was disinfected with $70 \% \mathrm{v} / \mathrm{v}$ ethanol and a partial thickness burn wound was created by using $2 \mathrm{gm}$ of hot molten bees' wax at $80^{\circ} \mathrm{C}$ poured to a metal cylinder with $300 \mathrm{~mm}^{2}$ circular openings placed on the back of the animal. On solidification of wax after 8 minutes the metal cylinder with wax adhered to the skin removed and left markedly circular burn wound. Burn wound healing parameters (wound contraction rate and epithelialization period) were assessed. ${ }^{91}$ 


\section{Histopathological Study}

Samples from healed skin tissue were taken from the mice of controls and treated groups of excision and burn wound models. ${ }^{92}$ Excised tissues were fixed in $10 \%$ formalin solution for five days. All tissues were processed by using conventional histochemical techniques, embedded in paraffin wax, and then sectioned at $3 \mu \mathrm{m}$ thicknesses, mounted on glass slides, deparaffinized, and stained with Hematoxylin-Eosin. ${ }^{2,93}$ The analysis was performed to confirm the experimental results in terms of concentration of inflammatory cells, collagen fibers, fibroblasts, and angiogenesis in tissue at 18 th post wounding days. ${ }^{94}$

\section{Statistical Analysis}

The results were expressed as mean \pm SEM for each group. All the grouped data were statistically evaluated and the significance of various treatments was calculated using one-way ANOVA followed by Tukey's post hoc test. The results were considered statistically significant at $95 \%$ confidence level and P-value $<0.05$. All data processing was done using SPSS data analysis software version 26.

\section{Results}

\section{Percentage Yields of Extracts}

The percentage yield of crude extract and solvent fractions of leaves of Vernonia auriculifera Hiern is shown in Table 1.

\section{Preliminary Phytochemical Screening}

The phytoscreening of the crude extracts and their respective fractions revealed the presence of the phytoconstituents as shown in Table 2.

\section{Acute Dermal Toxicity}

The maximum concentration of hydro-methanol ointment $(10 \% \mathrm{w} / \mathrm{w})$ was applied using a limit dose of $2000 \mathrm{mg} / \mathrm{kg}$ of body weight was found to be safe. The primary irritation index (PII) values were found to be zero, hence, there were no signs of toxicity after 14 days of assessment.

Table I Percentage Yield of Crude Extract and Solvent Fractions of Leaves of Vernonia auriculifera Hiern

\begin{tabular}{|l|l|l|l|l|}
\hline $\begin{array}{l}\text { Extract/ } \\
\text { Solvent } \\
\text { Fraction }\end{array}$ & $\begin{array}{l}\text { Crude } \\
\text { Extract }\end{array}$ & $\begin{array}{l}\text { Aqueous } \\
\text { Fraction }\end{array}$ & $\begin{array}{l}\text { Ethyl } \\
\text { Acetate } \\
\text { Fraction }\end{array}$ & $\begin{array}{l}\text { Chloroform } \\
\text { Fraction }\end{array}$ \\
\hline $\begin{array}{l}\text { Percentage } \\
\text { Yeild }\end{array}$ & $13.06 \%$ & $40.9 \%$ & $14.7 \%$ & $26.52 \%$ \\
\hline
\end{tabular}

Table 2 Results of Preliminary Phytochemical Screening of Crude Extract and Solvent Fractions

\begin{tabular}{|l|l|l|l|l|}
\hline $\begin{array}{l}\text { Secondary } \\
\text { Metabolites }\end{array}$ & $\begin{array}{l}\text { Crude } \\
\text { Extract }\end{array}$ & $\begin{array}{l}\text { Aqueous } \\
\text { Fraction }\end{array}$ & $\begin{array}{l}\text { Ethyl } \\
\text { Acetate } \\
\text { Fraction }\end{array}$ & $\begin{array}{l}\text { Chloroform } \\
\text { Fraction }\end{array}$ \\
\hline Alkaloids & - & - & - & - \\
Flavonoids & + & - & - & + \\
Glycosides & - & - & - & - \\
Phenols & - & + & + & - \\
Saponins & + & - & - & - \\
Steroids & - & - & - & - \\
Tannins & + & + & + & + \\
Terpenoids & + & + & + & + \\
\hline
\end{tabular}

Notes: Where $(+)=$ present, and $(-)=$ absent.

\section{Excision Wound Model Wound Contraction}

Wound contraction due to treatment with $5 \% \mathrm{w} / \mathrm{w}$ and $10 \%$ w/w crude extract of Vernonia auriculifera Hiern ointment, simple ointment base, and Nitrofurazone is shown in Table 3. The $10 \% \mathrm{w} / \mathrm{w}$ ointment of the crude extract showed significant $(\mathrm{P}<0.001)$ wound healing activity beginning from day 4 to day 18 compared to the negative control. Similarly, Vernonia auriculifera Hiern 5\% w/w ointment has shown a significant wound contraction at 4th, 6th, 8th, and 10th $(\mathrm{P}<$ $0.05)$ and on day 12 th $(\mathrm{P}<0.01)$ when compared to the negative control. Significant $(\mathrm{P}<0.001)$ wound contraction was observed in 5\% w/w extract on 14th, 16th, and 18th days of treatment when compared to the negative control. The percentage contraction was significant $(\mathrm{P}<0.001)$ for nitrofurazone from day six onwards as compared to the negative control and also significant wound contraction was observed on the 2 nd day $(\mathrm{P}<0.05)$ and 4 th day $(\mathrm{P}<0.01)$, respectively. Higher percentages of wound contraction $(98.11 \%$ and $100 \%$ ) were observed in animals treated with the $10 \%$ extract ointment from the 16th and 18th day, respectively Table 3. When compared with positive control, statistically significant better effect was not found.

\section{Period of Epithelialization}

Wound healing effects of both $5 \% \mathrm{w} / \mathrm{w}$ and $10 \% \mathrm{w} / \mathrm{w}$ ointments of crude extract were indicated by a shorter period of epithelialization. The $5 \% \mathrm{w} / \mathrm{w}$ extract formulation showed a significant $(\mathrm{P}<0.001)$ difference of epithelialization period as compared to the negative control whereas the $10 \% \mathrm{w} / \mathrm{w}$ extract ointment treated group showed a significant $(\mathrm{P}<0.05)$ difference of epithelialization period as compared to the negative control and it also 
Table 3 Effect of Vernonia auriculifera Crude Extract on Excision Wound Area in $\mathrm{mm}^{2}$ in Mice

\begin{tabular}{|c|c|c|c|c|}
\hline Days & Negative Control & $5 \%$ w/w Vernonia auriculifera Hiern & 10\% w/w Vernonia auriculifera Hiern & Positive Control \\
\hline & \multicolumn{4}{|c|}{ Wound area in $\mathrm{mm}^{2} \pm \mathrm{SEM}$ (\% contraction) } \\
\hline 2 & $262.67 \pm 1.36(12.66)$ & $238.17 \pm 1.62^{\mathrm{A} 3 \mathrm{C} 3 \mathrm{D} 3}(20.66)$ & $224.33 \pm 1.09^{\mathrm{A} 3 \mathrm{~B} 3}(25.33)$ & $219.17 \pm 1.08^{\mathrm{A} 3 \mathrm{~B} 3}(26.75)$ \\
\hline 4 & $23 I \pm 0.8 I(23.00)$ & $200 \pm 0.5 \mathrm{I}^{\mathrm{A3C3D} 3}(3 \mathrm{I} .64)$ & $182 \pm 0.36^{\mathrm{A} 3 \mathrm{~B} 3 \mathrm{D} 2}(39.33)$ & $177 \pm 1.30^{\mathrm{A} 3 \mathrm{~B} 3 \mathrm{C} 2}(40.76)$ \\
\hline 6 & $213 \pm 0.72(29.00)$ & $169 \pm 0.63^{\mathrm{A} 3 \mathrm{C} 3 \mathrm{D} 3}(43.66)$ & $136 \pm\left. 0.5\right|^{\mathrm{A3B3}}(54.45)$ & $134 \pm 0.63^{\mathrm{A3B} 3}(55.09)$ \\
\hline 8 & $|75 \pm 0.5|(41.66)$ & $126 \pm 0.36^{\mathrm{A} 3 \mathrm{C} 3 \mathrm{D} 3}(58.00)$ & $91 \pm 0.36^{\mathrm{A3B} 3 \mathrm{DI}}(69.42)$ & $89 \pm 0.51^{\mathrm{A} 3 \mathrm{~B} 3 \mathrm{Cl}}(70.06)$ \\
\hline 10 & $155 \pm 0.77(45.94)$ & $104 \pm 0.5 \mathrm{I}^{\mathrm{A3C} 3 \mathrm{D} 3}(65.28)$ & $64.67 \pm 0.66^{\mathrm{A} 3 \mathrm{~B} 3}(78.02)$ & $64 \pm 0.68^{\mathrm{A} 3 \mathrm{~B} 3}(78.66)$ \\
\hline 12 & $131 \pm 0.36(53.33)$ & $72.00 \pm 0.51^{\mathrm{A} 3 \mathrm{C} 3 \mathrm{D} 3}(76.0)$ & $36.83 \pm 0.65^{\mathrm{A} 3 \mathrm{~B} 3}(87.57)$ & $36 \pm 0.57^{\mathrm{A} 3 \mathrm{~B} 3}(87.89)$ \\
\hline 14 & $98.5 \pm 0.88(64.01)$ & $38.83 \pm 0.47^{\mathrm{A} 3 \mathrm{C} 3 \mathrm{D} 3}(86.94)$ & $21 \pm 0.36^{\mathrm{A} 3 \mathrm{~B} 3}(93.00)$ & $20 \pm 0.36^{\mathrm{A} 3 \mathrm{~B} 3}(93.3 \mathrm{I})$ \\
\hline 16 & $70.17 \pm 0.47(76.61)$ & $20.83 \pm 0.30^{\mathrm{A} 3 \mathrm{C} 3 \mathrm{D} 3}(93.05)$ & $5.67 \pm 0.33^{\mathrm{A} 3 \mathrm{~B} 3}(98.1 \mathrm{I})$ & $4.83 \pm 0.40^{\mathrm{A} 3 \mathrm{~B} 3}(98.38)$ \\
\hline 18 & $5.83 \pm 0.30(98.05)$ & $5.83 \pm 0.30^{\mathrm{A3C3D} 3}(98.05)$ & $0.00 \pm 0.00^{\mathrm{A3B} 3}(100)$ & $0.00 \pm 0.00^{\mathrm{A} 3 \mathrm{~B} 3}(100)$ \\
\hline EPD & $21.17 \pm 0.60$ & $19.17 \pm\left. 0.9\right|^{\mathrm{A} 3}$ & $17.83 \pm 0.60^{\mathrm{Al}}$ & $17.67 \pm 0.42^{\mathrm{A} 2}$ \\
\hline
\end{tabular}

Notes: Values are expressed as Mean \pm SEM, values in parenthesis indicate $\%$ wound contraction; $n=6$; ${ }^{A}$ Compared to the negative control, ${ }^{\mathrm{B}}$ Compared to the $5 \%$ w/w crude extract, ${ }^{C}$ Compared to the $10 \% \mathrm{w} / \mathrm{w}$ crude extract, ${ }^{\mathrm{D}}$ Compared to the positive control; ${ }^{\prime}=\mathrm{P}<0.05,{ }^{2}=\mathrm{P}<0.01,{ }^{3}=\mathrm{P}<0.001$.

Abbreviation: EPD, Epithelialization Days.

showed shorter period epithelialization as compared to the $5 \% \mathrm{w} / \mathrm{w}$ extract. On average, the period of epithelialization was $21.17,19.17,17.83$, and $17.67 \%$ for the negative control, $5 \% \mathrm{w} / \mathrm{w}, 10 \% \mathrm{w} / \mathrm{w}$, and positive control, respectively.

The wound healing activity of solvent fractions in the excision wound model was found to be significant. Groups treated with the ethyl acetate and aqueous fraction ointments showed significant $(\mathrm{P}<0.05)$ wound healing activity in comparison with the negative control from day 4 to day 16 but chloroform fraction failed to show statistically significant wound healing activity when compared to the negative control (Table 4). The standard ointment treated group was showed statistically significant wound healing $(\mathrm{P}<0.001)$ from 4 to day 16 and significant $(\mathrm{P}<0.001)$ at day 2 when compared to the negative control. Groups of mice treated with the $10 \%$ $\mathrm{w} / \mathrm{w}$ ethyl acetate fraction, $5 \% \mathrm{w} / \mathrm{w}$ aqueous fraction, $10 \% \mathrm{w} /$ $\mathrm{w}$ aqueous fraction, and standard ointments revealed a statistically significant shorter period of epithelialization ( $\mathrm{P}$ $<0.001)$ compared to the negative control. However, there was no significant difference in the epithelialization period among the $10 \% \mathrm{w} / \mathrm{w}$ ointment of ethyl acetate and aqueous fractions. Among the fractions, groups of mice treated with $10 \% \mathrm{w} / \mathrm{w}$ aqueous fraction ointment had the shortest periods of epithelialization (16.16 days) compared to other fractions. When compared with positive control, statistically significant better effect was not found.

\section{Incision Wound Model}

\section{Incision Model for Crude Extract}

The mean tensile strength in the group treated with a simple ointment base tended to increase by about $10.59 \%$ compared to untreated controls, which failed to reach statistical significance. The $10 \% \mathrm{w} / \mathrm{w}$ of the crude extract ointment treated groups showed a significant $(\mathrm{P}<0.001)$ increase in tensile strength compared to simple ointment and the untreated control group. Simple ointment treated groups did not show a statistically significant increase in breaking strength when compared to the untreated control group. The tensile strength of mice treated with the $10 \% \mathrm{w} / \mathrm{w}$ drug was significantly higher $(\mathrm{P}<0.01)$ than the $5 \% \mathrm{w} / \mathrm{w}$ extract-treated animals; however, no apparent difference was detected with standard treated groups Table 5. When compared with positive control, statistically significant better effect was not found.

\section{Incision Model for Solvent Fractions}

As described in Table 6, among the solvent fraction; ethyl acetate and aqueous fractions were found to show a statistically significant $(\mathrm{P}<0.001)$ increase in tensile strength when compared to both simple ointment and the untreated control groups. The $10 \% \mathrm{w} / \mathrm{w}$ chloroform fraction was not significant as compared to the negative control and untreated groups. The $10 \%$ aqueous $\mathrm{w} / \mathrm{w}$ ointment was found to show a statistically significant difference $(P<0.001)$ in tensile strength compared to the control groups, chloroform fractions, and untreated group. However, there was no statistically significant difference observed between the $5 \% \mathrm{w} / \mathrm{w}$, $10 \% \mathrm{w} / \mathrm{w}$ ethyl acetate, and aqueous fraction ointments. When compared with positive control, statistically significant better effect was not found.

\section{Burn Wound Model}

According to Table 7, increased percentage of wound contraction and reduced period of epithelialization observed in both 
Table 4 Effect of Vernonia auriculifera Hiern Fractions on Excision Wound in Mice

\begin{tabular}{|c|c|c|c|c|c|c|c|c|}
\hline Group & Day_2 & Day_4 & Day_6 & Day_8 & Day_10 & Day_12 & Day_14 & Day_16 \\
\hline $\begin{array}{l}\text { Negative } \\
\text { control }\end{array}$ & $\begin{array}{l}255.00 \pm 0.52 \\
(15.00)\end{array}$ & $\begin{array}{l}233.13 \pm 0.48 \\
(22.29)\end{array}$ & $\begin{array}{l}204.16 \pm 0.60 \\
(31.94)\end{array}$ & $\begin{array}{l}167.20 \pm 1.11 \\
(44.26)\end{array}$ & $\begin{array}{l}129 \pm 1.00 \\
(157.00)\end{array}$ & $\begin{array}{l}94.66 \pm 1.12 \\
(68.44)\end{array}$ & $\begin{array}{l}68.83 \pm 0.60 \\
(70.05)\end{array}$ & $\begin{array}{l}35.83 \pm 0.40 \\
(88.05)\end{array}$ \\
\hline $\begin{array}{l}\text { Chloroform } \\
\text { fraction } 5 \%\end{array}$ & $\begin{array}{l}245.83 \pm 0.48 \\
(18.33)\end{array}$ & $\begin{array}{l}225.83 \pm 0.40 \\
(24.72)\end{array}$ & $\begin{array}{l}177.33 \pm 0.92 \\
(40.88)\end{array}$ & $\begin{array}{l}141.17 \pm 0.79 \\
(52.94)\end{array}$ & $\begin{array}{l}110.5 \pm 0.56 \\
(63.16)\end{array}$ & $\begin{array}{l}78.5 \pm 0.22 \\
(73.83)\end{array}$ & $\begin{array}{l}41.33 \pm 0.33 \\
(86.22)\end{array}$ & $\begin{array}{l}23.66 \pm 0.72 \\
(92.11)\end{array}$ \\
\hline $\begin{array}{l}\text { Chloroform } \\
\text { fraction } 10 \%\end{array}$ & $\begin{array}{l}244 \pm 0.52 \\
(18.66)\end{array}$ & $\begin{array}{l}215.17 \pm 0.60 \\
(28.27)\end{array}$ & $\begin{array}{l}179 \pm 1.24 \\
(40.33)\end{array}$ & $\begin{array}{l}138.00 \pm 1.00 \\
(54.00)\end{array}$ & $\begin{array}{l}108.5 \pm 1.02 \\
(63.83)\end{array}$ & $\begin{array}{l}78.16 \pm 0.54 \\
(73.94)\end{array}$ & $\begin{array}{l}40.5 \pm 0.50 \\
(86.50)\end{array}$ & $\begin{array}{l}19.67 \pm 0.42 \\
(93.44)\end{array}$ \\
\hline $\begin{array}{l}\text { Ethyl acetate } \\
\text { fraction } 5 \%\end{array}$ & $\begin{array}{l}240 \pm 0.73 \\
(20.00)\end{array}$ & $\begin{array}{l}210.67 \pm 1.05^{\mathrm{A} *} \\
(29.77)\end{array}$ & $\begin{array}{l}176 \pm 1.03^{A} * \\
(41.33)\end{array}$ & $\begin{array}{l}128.83 \pm 0.79^{A_{*}} \\
(57.05)\end{array}$ & $\begin{array}{l}93.33 \pm 0.76^{A_{*}} \\
(68.88)\end{array}$ & $\begin{array}{l}58.50 \pm 0.22^{A} * \\
(80.5)\end{array}$ & $\begin{array}{l}27.66 \pm 0.33^{A *} \\
(70.77)\end{array}$ & $\begin{array}{l}5.8 \pm 0.70^{\mathrm{A} *} \\
(98.05)\end{array}$ \\
\hline $\begin{array}{l}\text { Ethyl acetate } \\
\text { fraction } 10 \%\end{array}$ & $\begin{array}{l}239 \pm 0.93 \\
(20.33)\end{array}$ & $\begin{array}{l}209.83 \pm 0.98^{A_{*} *} \\
(30.05)\end{array}$ & $\begin{array}{l}157.50 \pm 1.87^{A *} \\
(47.50)\end{array}$ & $\begin{array}{l}I 12.33 \pm 0.68^{A_{*}} \\
(62.55)\end{array}$ & $\begin{array}{l}83.16 \pm 0.54^{A_{*}^{*}} \\
(72.28)\end{array}$ & $\begin{array}{l}53.83 \pm 1.14^{\mathrm{A} *} \\
(82.05)\end{array}$ & $\begin{array}{l}22.66 \pm 0.42^{A *} \\
(92,44)\end{array}$ & $\begin{array}{l}1.5 \pm 0.22^{A *} \\
(99.5)\end{array}$ \\
\hline $\begin{array}{l}\text { Aqueous } \\
\text { fraction } 5 \%\end{array}$ & $\begin{array}{l}235.85 \pm 0.30 \\
(21.66)\end{array}$ & $\begin{array}{l}207.83 \pm 0.48^{A *} \\
(30.72)\end{array}$ & $\begin{array}{l}167.83 \pm 0.70^{A *} \\
(44.05)\end{array}$ & $\begin{array}{l}119.16 \pm 0.98^{\mathrm{A} *} \\
(60.27)\end{array}$ & $\begin{array}{l}89.5 \pm 0.67^{A_{*}} \\
(70.17)\end{array}$ & $\begin{array}{l}56.16 \pm 0.95^{\mathrm{A} *} \\
(81.12)\end{array}$ & $\begin{array}{l}24.83 \pm 0.87^{A *} \\
(91.72)\end{array}$ & $\begin{array}{l}2.50 \pm 0.43^{A_{*}} \\
(99.16)\end{array}$ \\
\hline $\begin{array}{l}\text { Aqueous } \\
\text { fraction } 10 \%\end{array}$ & $\begin{array}{l}231.33 \pm 0.67 \\
(23.00)\end{array}$ & $\begin{array}{l}188.17 \pm 0.70^{A *} \\
(32.27)\end{array}$ & $\begin{array}{l}159 \pm 0.52^{A *} \\
(47.00)\end{array}$ & $\begin{array}{l}I 10.66 \pm 0.88^{A *} \\
(63.11)\end{array}$ & $\begin{array}{l}74.83 \pm 0.60^{A *} \\
(75.05)\end{array}$ & $\begin{array}{l}45.16 \pm 0.54^{\mathrm{A} *} \\
(84.94)\end{array}$ & $\begin{array}{l}15.00 \pm 0.26^{A} * \\
(95.00)\end{array}$ & $\begin{array}{l}2.00 \pm 0.00^{A_{3}} \\
(99.33)\end{array}$ \\
\hline Positive control & $\begin{array}{l}205.17 \\
\pm 0.60^{\mathrm{A} *} \\
(31.66)\end{array}$ & $\begin{array}{l}183.83 \pm \\
1.01^{\mathrm{A} * * * *} \\
(38.72)\end{array}$ & $\begin{array}{l}181.67 \pm \\
0.92^{A} * * * \\
(39.44)\end{array}$ & $\begin{array}{l}106.83 \\
\pm 0.95^{A_{* * *}} \\
(64.38)\end{array}$ & $\begin{array}{l}74.66 \pm \\
0.33^{\mathrm{A}} * * * * \\
(75.11)\end{array}$ & $\begin{array}{l}46.00 \pm \\
0.52^{A_{*} * * *} \\
(84.66)\end{array}$ & $\begin{array}{l}16.17 \pm \\
0.48^{A} * * * \\
(94.61)\end{array}$ & $\begin{array}{l}1.50 \pm \\
0.22^{\mathrm{A}_{* * * *}} \\
(99.50)\end{array}$ \\
\hline
\end{tabular}

Notes: Values are expressed as Mean \pm SEM, values in parenthesis indicate \% wound contraction; $\mathrm{n}=6 ;{ }^{\mathrm{A} C o m p a r e d ~ t o ~ t h e ~ n e g a t i v e ~ c o n t r o l, ~} * \mathrm{P}<0.05$, $* * \mathrm{P}<0.0 \mathrm{I},{ }^{*} * * \mathrm{P}<0.00 \mathrm{I}$.

Table 5 Effects of Crude Extract of Vernonia auriculifera Hiern Ointments on Tensile Strength

\begin{tabular}{|l|l|l|}
\hline Group & Breaking Strength (gm) & \% Tensile Strength \\
\hline Left untreated & $192.46 \pm 2.23$ & - \\
Negative control & $212.85 \pm 13.71$ & 10.59 \\
V. auriculifera Hiern 5\% w/w & $304.31 \pm 5.26$ & 42.97 \\
V. auriculifera Hiern 10\% w/w & $340.63 \pm 11.16^{\mathrm{A} * * * \mathrm{~B} * * *}$ & 60.03 \\
Positive control & $347.07 \pm 14.58^{\mathrm{A} * * * \mathrm{~B} * * *}$ & 63.05 \\
\hline
\end{tabular}

Notes: Values are expressed as Mean \pm SEM, $n=6 ;{ }^{A}=$ as compared to simple ointment (negative control), ${ }^{B}=$ as compared to $5 \%$ crude extract ointment, $* * * P<0.001$.

Table 6 Effects of the Solvent Fractions of Vernonia auriculifera Hiern Ointments on Tensile Strength of Incision Model in Mice

\begin{tabular}{|l|l|l|}
\hline Group & Breaking Strength (gm) & \% Tensile Strength \\
\hline Left untreated & $217.18 \pm 22.15$ & - \\
Negative control & $264.33 \pm 11.06$ & 21.7 \\
Chloroform 5\% w/w & $335.92 \pm 15.92^{\mathrm{A} * * * \mathrm{~B} * * *}$ & 34.65 \\
Chloroform 10\% w/w & $352.40 \pm 20.5884^{\mathrm{A} * * * \mathrm{~B} * * * \mathrm{C} * * *}$ & 51.90 \\
Ethyl acetate 5\% w/w & $432.82 \pm 21.84^{\mathrm{A} * * * \mathrm{~B} * * * \mathrm{C} * * * \mathrm{D} * * *}$ & 63.74 \\
Ethyl acetate 10\% w/w & $437.20 \pm 17.44^{\mathrm{A} * * * \mathrm{~B} * * * \mathrm{C} * * * \mathrm{D} * * *}$ & 65.40 \\
Aqueous 5\% w/w & $452.47 \pm 16.74^{\mathrm{A} * * * \mathrm{~B} * * * \mathrm{C} * * * \mathrm{D} * * *}$ & 71.17 \\
Aqueous 10\% w/w & $489.77 \pm 31.40^{\mathrm{A} * * * \mathrm{~B} * * * \mathrm{C} * * * \mathrm{D} * * * * * * *}$ & 89.29 \\
Nitrofrazone 0.2\% & $499.40 \pm 29.88^{\mathrm{A} * * * \mathrm{~B} * * * \mathrm{C} * * * \mathrm{D} * * *}$ & 88.93 \\
\hline
\end{tabular}

Notes: Values are expressed as Mean \pm SEM; $n=6 ;{ }^{A}=$ as compared to simple ointment (negative control), ${ }^{\mathrm{B}}=$ as compared to left untreated, ${ }^{\mathrm{C}}=$ as compared to $5 \%$ chloroform fraction, ${ }^{\mathrm{D}}=$ as compared to $10 \%$ chloroform fraction, ${ }^{\mathrm{E}}=$ as compared to Ethyl acetate $5 \%,{ }^{\mathrm{F}}=$ as compared to Ethyl acetate $10 \%,{ }^{\mathrm{G}}=$ as compared to $A$ queous $5 \%$,

$\mathrm{H}=$ as compared to $10 \%$ aqueous, ${ }^{\prime}=$ as compared to standard, $* * * \mathrm{P}<0.001$.

$10 \% \mathrm{w} / \mathrm{w}$ and $5 \% \mathrm{w} / \mathrm{w}$ ointments of Vernonia auriculifera Herin crude extract. Silver sulfadiazine $1 \%$ and $10 \% \mathrm{w} / \mathrm{w}$ ointment of crude extract-treated groups produced significant
( $\mathrm{P}<0.001$ ) wound contraction in most post wounding days when compared to the negative control. The $5 \% \mathrm{w} / \mathrm{w}$ ointment of the crude extract also showed statistically significant wound 
Table 7 Effect of Vernonia auriculifera Hiern Crude Extract on Burn Wound Model in Mice

\begin{tabular}{|c|c|c|c|c|}
\hline Days & Simple Ointment & $5 \%$ w/w Vernonia auriculifera Hiern & I0\% w/w Vernonia auriculifera Hiern & SSD I\% Ointment \\
\hline & \multicolumn{4}{|c|}{ Wound area in $\mathrm{mm}^{2}$ (mean $\pm \mathrm{ME}$ ) and Percentage of wound contraction } \\
\hline 2 & $\begin{array}{l}234 \pm 0.30 \\
(21.97)\end{array}$ & $\begin{array}{l}234 \pm 0.40 \\
(21.97)\end{array}$ & $\begin{array}{l}234 \pm 0.49^{\mathrm{A} * * *} \\
(21.97)\end{array}$ & $\begin{array}{l}234 \pm 0.48^{\mathrm{A} * * *} \\
(21.97)\end{array}$ \\
\hline 4 & $\begin{array}{l}189 \pm 0.44 \\
(37)\end{array}$ & $\begin{array}{l}139 \pm 0.30 \\
(53.66)\end{array}$ & $\begin{array}{l}103 \pm 0.30^{\mathrm{A} * * *} \\
(65.66)\end{array}$ & $\begin{array}{l}104 \pm 0.60^{\mathrm{A} * * *} \\
(65.33)\end{array}$ \\
\hline 6 & $\begin{array}{l}154 \pm 0.36 \\
(48.66)\end{array}$ & $\begin{array}{l}105 \pm 0.40^{A} * \\
(64.97)\end{array}$ & $\begin{array}{l}68 \pm 0.36^{\mathrm{A} * * *} \\
(77.33)\end{array}$ & $\begin{array}{l}70 \pm 0.30^{\mathrm{A} * * *} \\
(76.66)\end{array}$ \\
\hline 8 & $\begin{array}{l}|16 \pm 0.5| \\
(61.33)\end{array}$ & $\begin{array}{l}74 \pm 0.40^{A} * \\
(75.15)\end{array}$ & $\begin{array}{l}37 \pm 0.36^{\mathrm{A} * * *} \\
(87.66)\end{array}$ & $\begin{array}{l}36 \pm 0.36^{\mathrm{A} * * *} \\
(88.00)\end{array}$ \\
\hline 10 & $\begin{array}{l}77 \pm 0.47 \\
(74.33)\end{array}$ & $\begin{array}{l}47 \pm 0.25^{\mathrm{A} *} \\
(84.07)\end{array}$ & $\begin{array}{l}21.00 \pm 0.3^{A * * *} \\
(93.00)\end{array}$ & $\begin{array}{l}9 . \pm 0.30^{\mathrm{A} * * *} \\
(97.00)\end{array}$ \\
\hline 12 & $\begin{array}{l}35.83 \pm 0.47 \\
(88.05)\end{array}$ & $\begin{array}{l}24 \pm 0.36^{\mathrm{A} *} \\
(91.74)\end{array}$ & $\begin{array}{l}10 \pm 0.36^{\mathrm{A} * * *} \\
(96.7)\end{array}$ & $\begin{array}{l}9 \pm 0.30^{\mathrm{A} * * *} \\
(97.00)\end{array}$ \\
\hline 14 & $\begin{array}{l}35.83 \pm 0.47 \\
(88.05)\end{array}$ & $\begin{array}{l}9.67 \pm 0.66^{\mathrm{A} * *} \\
(96.77)\end{array}$ & $\begin{array}{l}2.83 \pm 0.30^{\mathrm{A} * * *} \\
(99.05)\end{array}$ & $\begin{array}{l}1.83 \pm 0.30^{\mathrm{A} * * *} \\
(99.38)\end{array}$ \\
\hline 16 & $\begin{array}{l}17.83 \pm 0.30 \\
(94.05)\end{array}$ & $\begin{array}{l}2.5 \pm 0.22^{A} * * \\
(99.16)\end{array}$ & $\begin{array}{l}0.00 \pm 0.00^{\mathrm{A} * * *} \\
(100.00)\end{array}$ & $\begin{array}{l}0.00 \pm 0.00^{\mathrm{A} * * *} \\
(100.00)\end{array}$ \\
\hline EPD & 19.16 & $16.67^{\mathrm{A} *}$ & $14.5^{\mathrm{A} * * *}$ & $14.33^{\mathrm{A} * * *}$ \\
\hline
\end{tabular}

Notes: Values are expressed as Mean $\pm \mathrm{SEM}$, values in parenthesis indicate $\%$ wound contraction; $\mathrm{n}=6{ }^{\mathrm{A}}{ }^{\mathrm{A}}=$ compared to the negative control, $* \mathrm{P}<0.05, * * \mathrm{P}<0.01, * * * \mathrm{P}<$ $0.00 \mathrm{I}$; Initial wound area was $300 \mathrm{~mm} 2$.

Abbreviations: EPD, epithelialization Days; SSD, silver sulfadiazine ointment.

healing activity within $6-12$ days $(\mathrm{P}<0.05)$ and at 14 th and 16th $(\mathrm{P}<0.01)$ days of treatment compared to the negative control. However, no significant difference was observed in wound contraction in groups treated with $10 \%$ w/wand the positive control ointments. Groups of mice treated with the $5 \%$ $\mathrm{w} / \mathrm{w}$ crude extract ointment resulted in a significant $(\mathrm{P}<0.05)$ reduction in the period of epithelialization when compared to the negative control. The $10 \% \mathrm{w} / \mathrm{w}$ crude extract ointment and the standard showed significant $(\mathrm{P}<0.001)$ reduction in the period of epithelialization compared to the negative control. However, an insignificant difference in epithelialization period was observed among groups treated with $10 \% \mathrm{w} / \mathrm{w}, 5 \% \mathrm{w} / \mathrm{w}$ crude extract, and the standard ointments. When compared with positive control, statistically significant better effect was not found.

\section{Histopathological Analysis of Skin Tissue}

Histopathological analysis was performed in excision wound model of crude and solvent fractions as well as burn wound model. As shown in Table 8, granulation tissue of healed wound in standard and extract-treated groups showed few concentrations of inflammatory cells, as well as a moderate concentration of collagen fiber, fibroblasts, and proliferating blood capillaries (angiogenesis) compared with control, treated group both in excision and burn wound models. Figure 1A-H. The negative control groups in both excision and burn wound models had fewer collagen fibers, fibroblasts and blood capillaries, and more inflammatory cells, and thus showed delayed wound healing processes Figure 1A and E. Likewise, in a majority of fraction-treated groups, few inflammatory cells, and more collagen fiber, fibroblasts and proliferating blood capillaries (angiogenesis) were observed as compared to the negative control-treated group Figure 1I-N (Table 8).

\section{Discussion}

A wound causes a major health problem, both in terms of morbidity and mortality. Proper healing of wounds is essential for the restoration of disrupted anatomical stability and functional status of the skin. ${ }^{95}$ Rapid wound healing requires fast wound contraction, a shorter epithelization period, and adequate gain of tensile strength. ${ }^{96}$ Herbal medicines play a vital role in developed, as well as developing, countries in improving primary healthcare because of their effective biological and 
Table 8 Histological Qualitative Determination of Wound Healing Processes of Crude Extract and Solvent Fractions of Vernonia auriculifera Hiern in Different Wound Healing Models

\begin{tabular}{|c|c|c|c|c|c|}
\hline Groups & FP & CD & MNC & PMN & NV \\
\hline \multicolumn{6}{|l|}{ Excision model } \\
\hline \multicolumn{6}{|l|}{ Crude extract } \\
\hline Simple ointment & - & - & +++ & ++ & + \\
\hline $5 \%(\mathrm{~W} / \mathrm{W})$ extract & ++ & ++ & + & + & + \\
\hline $10 \%(\mathrm{~W} / \mathrm{W})$ extract & ++ & +++ & + & - & + \\
\hline Nitrofurazone $0.2 \%$ & ++ & ++ & + & + & + \\
\hline \multicolumn{6}{|l|}{ Solvent fractions } \\
\hline Simple ointment & + & + & ++ & +++ & + \\
\hline Chloroform fraction $5 \%(\mathrm{~W} / \mathrm{W})$ & + & - & + & ++ & - \\
\hline Chloroform fraction $10 \%(\mathrm{~W} / \mathrm{W})$ & + & + & ++ & ++ & - \\
\hline Ethyl acetate fraction $5 \%(\mathrm{~W} / \mathrm{W})$ & ++ & ++ & + & + & ++ \\
\hline Ethyl acetate fraction $10 \%(\mathrm{~W} / \mathrm{W})$ & ++ & ++ & + & + & ++ \\
\hline Aqueous fraction $5 \%(\mathrm{~W} / \mathrm{W})$ & ++ & ++ & + & + & - \\
\hline Aqueous fraction $10 \%(\mathrm{~W} / \mathrm{W})$ & +++ & +++ & + & + & +++ \\
\hline Nitrofurazone $0.2 \%(\mathrm{~W} / \mathrm{W})$ & ++ & ++ & + & + & - \\
\hline \multicolumn{6}{|l|}{ Burn wound model } \\
\hline Simple ointment & + & + & ++ & +++ & - \\
\hline $5 \%(\mathrm{~W} / \mathrm{W})$ extract & + & ++ & - & - & + \\
\hline $10 \%(\mathrm{~W} / \mathrm{W})$ extract & ++ & ++ & + & + & - \\
\hline Silver sulfadiazine I\% & ++ & ++ & + & + & + \\
\hline
\end{tabular}

Notes: Low concentration $(+)$, moderate concentration $(++)$, and high concentration $(+++)$ for epidermal or dermal remodeling.

Abbreviations: FP, fibroblast proliferation; $C D$, collagen depositions; MNC, mononuclear cells; PMN, polymorphonuclear cells; NV, neovascularization.

medicinal properties. ${ }^{17}$ Among the plants, Vernonia auriculifera Hiern is the one that is traditionally claimed in various parts of Ethiopia, ${ }^{28,29,31,97,98}$ due to its immense potential to have wound healing activity. ${ }^{99}$ Despite the claim, no scientific study about the wound healing activity of the leaves of this plant in animal models has been reported. Therefore, this study aimed to evaluate the wound healing activity of the plant in mice using excision, incision and burn models.

Acute dermal toxicity test showed no signs of toxicity when the animals were monitored for 14 days and PII values were zero implying the non-irritant nature of the test samples as per the dermal irritation scoring system. ${ }^{80,82}$ Hence, leaves of Vernonia auriculifera extract formulation can be used safely as a topical preparation to treat wound.

The plant extract was formulated as an ointment base for topical application to achieve sustained drug release at the application site thereby facilitating wound healing process by preventing the escape of moisture from the skin, causes skin hydration, and also provides a medium for dissolution of the drug and keratinocyte migration. Ingredients of ointment base include hard and white soft paraffin which have a role in the formation of a barrier for moisture over the wound area whereas wool fat and cetostearyl alcohol are thickeners and used for stabilization of ointment. $^{100,101}$

Improved rate of wound contraction and reduction of healing time has been found in both $5 \% \mathrm{w} / \mathrm{w}(\mathrm{P}<0.05)$ and $10 \% \mathrm{w} / \mathrm{w}(\mathrm{P}<0.001)$ crude extract ointments in the excision and burn wound models. Although there was no statistically significant difference between extract-treated groups, the $10 \% \mathrm{w} / \mathrm{w}$ extract formulation showed better healing activity than the $5 \% \mathrm{w} / \mathrm{w}$ extract, and wound healing effect of $10 \% \mathrm{w} / \mathrm{w}$ extract was found to be comparable with a standard drug (nitrofurazone).

Contraction of the excision wound was facilitated by the plant extract and promoted till day eighteen in extract and standard treated groups. Hence, the $10 \% \mathrm{w} / \mathrm{w}(\mathrm{P}<0.001)$ extract ointment revealed a better observable effect compared to the negative control. However, it showed a statistically insignificant result when compared to the positive control. The $10 \% \mathrm{w} / \mathrm{w}(\mathrm{P}<0.001)$ aqueous fraction showed faster wound area contraction than $5 \% \mathrm{w} / \mathrm{w}$ chloroform and ethyl acetate fraction ointments from the 4th day onwards. Hence, the higher wound contraction rate of the $10 \% \mathrm{w} / \mathrm{w}$ aqueous fraction was possibly due to either its higher dose of antibacterial effect or induction of macrophage cell proliferation. ${ }^{102}$ The enhanced effect observed in the extracts may be associated with the ability of the extract to promote the proliferation of epithelial cells.

In excision wound model of crude extract, the period of epithelialization was reduced from 21.17 days (simple ointment) to $19.17,17.83$, and 17.67 days for $5 \% \mathrm{w} / \mathrm{w}(\mathrm{P}$ $<0.001)$ extract, $10 \% \mathrm{w} / \mathrm{w}(\mathrm{P}<0.05)$ extract and Nitrofurazone $(\mathrm{P}<0.001)$ treated groups, respectively. Similarly, it was greatly reduced in standard and aqueous fractions. This might be due to the ability of the plant extract to facilitate collagen synthesis, induction of cell proliferation, and antimicrobial activities of bioactive constituents. ${ }^{64}$

The wound healing activity of the extract was also evaluated in the incision wound model. Accordingly, the tensile strength of crude extracts of $10 \%$ ointment was statistically highly significant $(\mathrm{P}<0.001)$ as compared to simple ointment treated and untreated groups but it 

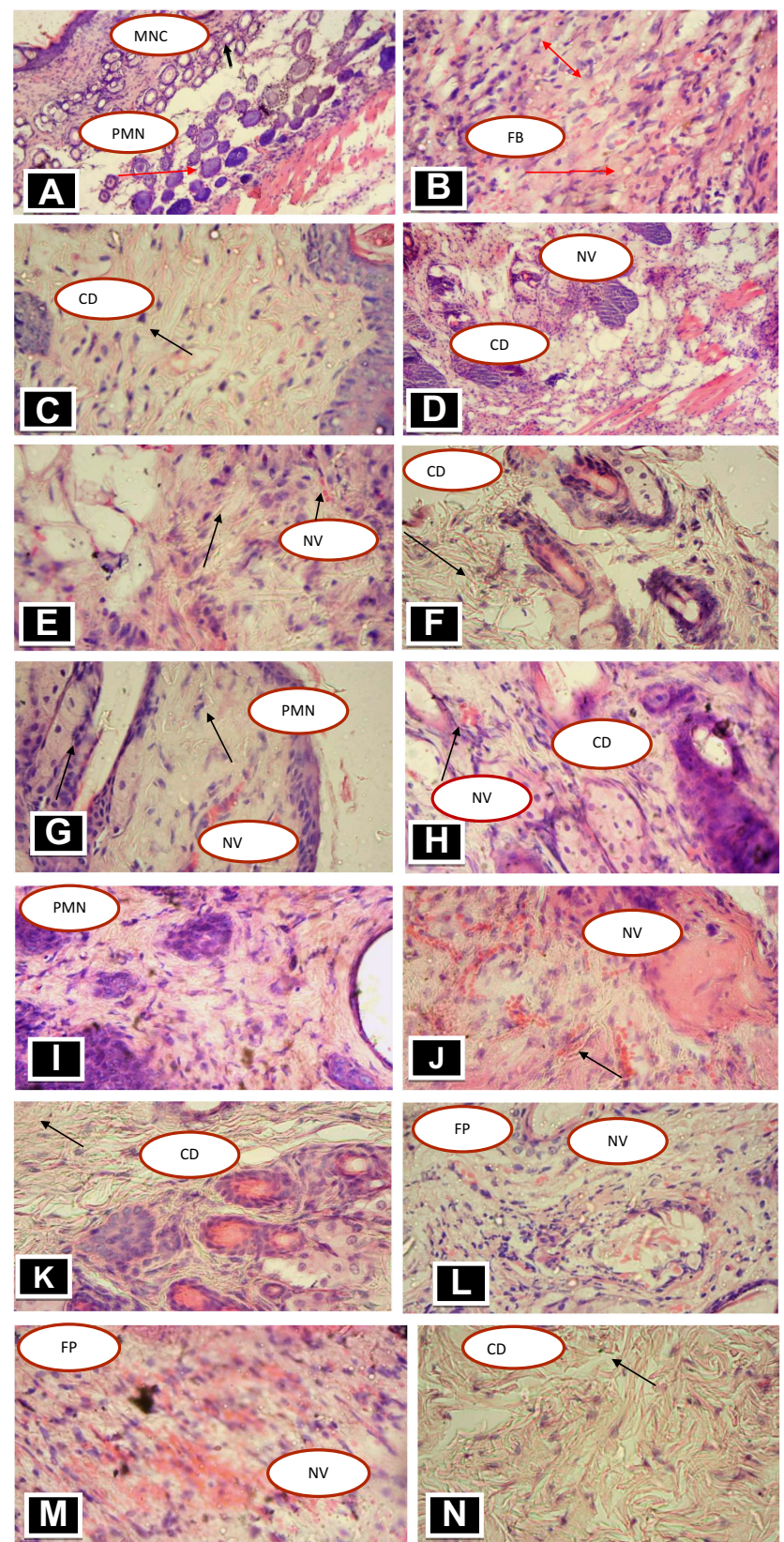

Figure I Photomicrographs of skin tissue $(\mathrm{H}$ and E x40) of crude and solvent fraction ointment treated mice in excision and burn wound models. (A) Mice treated with Negative control in excision wound model, (B) mice treated with $5 \%$ extract in excision wound, (C) mice treated with $10 \%$ extract in excision model, (D) mice treated with Nitrofurazone in excision wound, (E) mice treated with negative control in burn wound, $(\mathbf{F})$ mice treated with $5 \%$ in burn, $(\mathbf{G})$ mice treated with $10 \%$ extract in burn wound, $(\mathbf{H})$ mice treated with positive control in burn, (I) mice treated with negative control in fractions, (J) Mice treated with Ethyl acetate fraction $5 \%$, (K) mice treated with Ethyl acetate fraction I0\% (L) mice treated with $5 \%$ aqueous fraction, $(\mathbf{M})$ mice treated with $10 \%$ aqueous fractions, $(\mathbf{N})$ mice treated with positive control in fractions.

Abbreviations: CD, collagen deposition; D, dermis; E, epidermis; RE, re-epithelialization; HF, hair follicle; FP, fibroblast proliferation; MNC, Mononuclear cells; PMN, polymorphonuclear cells; NV, neovascularization.

showed slightly lesser strength as compared to the standard treated group. The tensile strength of a wound mainly depends upon the increase in collagen concentration and stabilization of the fibers. Hence, based on the histopathological analysis, it could be assumed that the $10 \% \mathrm{w} / \mathrm{w}$ extract ointment enhances the strength of the incision wound by increasing the collagen levels that stick the wound edges together at the repair site. ${ }^{103}$ Thus, the crude extract ointment might have roles in increasing tensile strength by facilitating collagen synthesis, maturation, stabilization, and improving angiogenesis.

Both aqueous and ethyl acetate fractions $(\mathrm{P}<0.001)$ in the incision wound model showed increased tensile strength compared to the negative control and chloroform fractions. 
This may be due to the astringent, antioxidant, and antibacterial properties of the phytoconstituents such as phenols and tannins in water and ethyl acetate fractions that enhance regeneration of new tissues. ${ }^{104}$ In the present study, relatively less concentration of inflammatory cells, and more collagen fiber, fibroblasts and angiogenesis were found in the crude extract of excision model, ethyl acetate fraction aqueous fraction, and crude extract of burn wound model.

A study conducted in South Africa shows that triterpenoids from Vernonia auriculifera Hiern exhibit antimicrobial activity. In the study, eight triterpenes and one aminated sesquiterpene were isolated from this plant and all compounds were tested against E. coli, P. aeruginosa, K. pneumoniae, S. aureus, B. subtilis, Enterococcus faecium, Staphylococcus epidermidis, and Staphylococcus saprophyticus. ${ }^{27}$

In another study, antimicrobial activity test has also been done and the qualitative crude methanolic leaves and stems extract activity result showed that Staphylococcus aureus and Staphylococcus epidermidis are found to be more susceptible. ${ }^{39}$

In addition, a study showed that Vernonia auriculifera possess antibacterial activities against the commonly wound infecting bacteria such as Staphylococcus aureus, Escherichia coli, and Pseudomonas aeruginosa and the microbial growth inhibition may be responsible for the wound healing effect of the plant by preventing infection and creating a clean wound bed for initiation and progression of the natural tissue repair process so that the overall time required for wound healing reduced significantly. ${ }^{105}$ Therefore, the in-vitro studies might support the wound healing activity of Vernonia auriculifera Herin by destructing wound surface contaminating pathogens.

Phytochemical screening test results showed the possible presence of flavonoids, phenols, saponins, tannins, and terpenoids. Similar studies on phytochemical screening of the methanol leaf extract of Vernonia auriculifera Hiern have been conducted and the result revealed the presence of secondary metabolites such as tannins, flavonoids, saponins, and terpenoids. ${ }^{62,105}$ The presence of flavonoids, phenols, and tannins had great implications for the enhanced wound healing activity that resulted by scavenging reactive oxygen species (ROS) thereby prevention of cells and tissue damage. ${ }^{106}$ Moreover, these secondary metabolites in the plant extract might also be attributed to the increased wound contraction and the reduced period of epithelialization. Tannins have astringent properties, hasten the healing of wounds. Saponins exhibit antioxidant and antibacterial property which appear to be important for wound contraction and an elevated rate of epithelization. ${ }^{107}$ Terpenoids promotes wound healing due to their astringent and antimicrobial property. In general, the observed wound healing activity may be due to the synergistic or independent action of the phytochemicals present in Vernonia auriculifera Hiern.

In all models used in the current study, even though promising result was found, but the extract and solvent fractions did not show significant significant better effect when compared with positive control. The effect of $10 \%$ ointment was especially promising. Studies by using other healing models would be important for further study.

\section{Conclusion}

The present study showed that $80 \%$ methanol extract and solvent fractions of the leaves of Vernonia auriculifera Hiern prepared as ointment formulations with a strength of $5 \% \mathrm{w} / \mathrm{w}$ and $10 \% \mathrm{w} / \mathrm{w}$ have rapid wound healing activity as compared to the simple ointment (negative control group). Among solvent fractions, ethyl acetate and aqueous fractions have shown significant wound healing activity. The presence of bioactive metabolites might be the reason for the extract to possessed wound healing activity. Thus, the results indicated that the leaves of Vernonia auriculifera Hiern possessed wound healing properties and these justify the use of the leaves of the plant for the treatment of wounds as claimed in the traditional medicine pieces of literature.

\section{Ethics Approval and Consent to Participate}

The study protocol was submitted and approved by the ethical review committee of Department of Pharmacology, College of Medicine and Health Sciences, University of Gondar with a Reference number of SoP4/285/12. The experiment was conducted in accordance with the guide for the care and use of laboratory animals. ${ }^{108}$

\section{Acknowledgments}

We would like to acknowledge the University of Gondar for approving the use of the laboratory facilities and Hawassa University for providing some financial support to purchase some chemicals.

\section{Funding}

This is a thesis work for the first author. Some financial support to purchase chemicals was found from Hawassa University because the university was a sponsor of MSc. study of the first author. 


\section{Disclosure}

The authors declare that they have no conflicts of interest for this work.

\section{References}

1. Mulisa E, Asres K, Engidawork E. Evaluation of wound healing and anti-inflammatory activity of the rhizomes of Rumex abyssinicus J.(Polygonaceae) in mice. BMC Complement Altern Med. 2015;15(1):341. doi:10.1186/s12906-015-0878-y

2. Nagar HK, Srivastava AK, Srivastava R, Kurmi ML, Chandel HS, Ranawat MS. Pharmacological investigation of the wound healing activity of Cestrum nocturnum (L.) ointment in wistar albino rats. $J$ Pharm. 2016;2016:1-8. doi:10.1155/2016/ 9249040

3. Sandeep D, Srija M, Suguna K, Varma RP, Rajesh S. A review on role of medicinal plants on Effective wound healing. Int $J$ Novel Trends Pharm Sci. 2015.

4. Barku VY. Wound healing: contributions from plant secondary metabolite antioxidants. Wound Heal Curr Persp. 2019.

5. Pattanayak SP, Sunita P. Wound healing, antimicrobial and antioxidant potential of Dendrophthoe falcata (L.f) Ettingsh J Ethnopharmacol. 2008;120:241. doi:10.1016/j.jep.2008.08.019

6. Sasidharan S, Nilawatyi R, Xavier R, Latha LY, Amala RJM. Wound healing potential of Elaeis guineensis Jacq leaves in an infected albino rat model. Molecules (Basel, Switzerland). 2010;15(5):3186-3199. doi:10.3390/molecules15053186

7. Beshir K, Shibeshi W, Ejigu A, Engidawork EJ. In-vivo wound healing activity of $70 \%$ ethanol leaf extract of Beciumgrandiflorum lamiaceae in Mice. Ethiop Pharm J. 2016;32:117-130.

8. Namunana S, Lutoti S, Nyamaizi G, et al. Formulation, development and validation of a wound healing herbal ointment from extracts of Bidens pilosa and Aloe barbadensis. J Med Educ Train. 2018;2:032-038.

9. Abdullahi A, Amini-Nik S, Jeschke M. Animal models in burn research. Cell Mol Life Sci. 2014;71(17):3241-3255. doi:10.1007/ s00018-014-1612-5

10. Laloto TL, Gemeda DH, Abdella SH. Incidence and predictors of surgical site infection in Ethiopia: prospective cohort. BMC Infect Dis. 2017;17(1):119. doi:10.1186/s12879-016-2167-x

11. Shiferaw WS, Aynalem YA, Akalu TY, Petrucka PM. Surgical site infection and its associated factors in Ethiopia: a systematic review and meta-analysis. BMC Surg. 2020;20:1-15. doi:10.1186/ s12893-020-00764-1

12. Sagbo IJ, Afolayan AJ, Bradley G. Antioxidant, antibacterial and phytochemical properties of two medicinal plants against the wound infecting bacteria. Asian Pac J Trop Biomed. 2017;7 (9):817-825. doi:10.1016/j.apjtb.2017.08.009

13. Atsbeha B, Mammo F, Kibret B. Phytochemical investigation on the leaves of Buddleja Polystachya (ethanol extract). Int J Integrat Sci Innov Technol. 2014;3:07-10.

14. Silambujanaki P, Chandra CBT, Kumar KA, Chitra V. Wound healing activity of Glycosmis arborea leaf extract in rats. J Ethnopharmacol. 2011;134(1):198-201. doi:10.1016/j.jep.2010.11.046

15. Mensah A, Sampson J, Houghton P, et al. Effects of Buddleja globosa leaf and its constituents relevant to wound healing. $J$ Ethnopharmacol. 2001;77(2):219-226. doi:10.1016/S03788741(01)00297-5

16. Perez-Gutierrez RM, Vargas-Solis R. Wound healing properties of triterpenes from Buddleia scordioides in diabetic rats. Pharm Biol. 2008;46(9):647-653. doi:10.1080/ 13880200802182471
17. Firdous SM, Sautya D. Medicinal plants with wound healing potential. Bangl J Pharmacol. 2018;13(1):41-52. doi:10.3329/ bjp.v13i1.32646

18. Maver T, Kurečič M, Smrke DM, Kleinschek KS, Maver U. Plant-derived medicines with potential use in wound treatment. Herbal Med. 2018.

19. Ijeh II, Ejike C. Current perspectives on the medicinal potentials of Vernonia amygdalina Del. J Med Plants Res. 2011;5 (7): 1051-1061.

20. Tessema Z, Makonnen E, Debella A, Molla Y. Evaluation of in vivo wound healing and anti-inflammatory activity of crude extract of the fruits of Brucea antidysentrica in mice. Wound Med. 2018;21:16-21. doi:10.1016/j.wndm.2018.05.005

21. Fikru A, Makonnen E, Eguale T, Debella A, Mekonnen GA. Evaluation of in vivo wound healing activity of methanol extract of Achyranthes aspera L. J Ethnopharmacol. 2012;143 (2):469-474. doi:10.1016/j.jep.2012.06.049

22. Mechesso AF, Tadese A, Tesfaye R, Tamiru W, Eguale T. Experimental evaluation of wound healing activity of Croton macrostachyus in rat. African J Pharm Pharmacol. 2016;10 (39):832-838. doi:10.5897/AJPP2015.4454

23. Shekhar P, Joshi A, Malviya S, Kharia A. Wound healing activity of the hydro-alcoholic extract of datura stramonium leaves in wistar albino rats. J Drug Deliv Therap. 2017;7(7):214-215.

24. Wabe N, Mohammed MA, Raju NJ. An ethnobotanical survey of medicinal plants in the Southeast Ethiopia used in traditional medicine. Spatula DD. 2011;1(3):153-158. doi:10.5455/ spatula.20110921101924

25. Isa AI, Saleh MIA, Abubakar A, et al. Evaluation of anti-inflammatory, antibacterial and cytotoxic activities of Cordia africana leaf and stem bark extracts. Bayero J Pure Appl Sci. 2016;9(1):228-235. doi:10.4314/bajopas.v9i1.36

26. Kipkore W, Wanjohi B, Rono H, Kigen G. A study of the medicinal plants used by the Marakwet Community in Kenya. $J$ Ethnobiol Ethnomed. 2014;10(1):24. doi:10.1186/1746-4269-10-24

27. Kiplimo JJ, Koorbanally NA, Chenia H. Triterpenoids from Vernonia auriculifera Hiern exhibit antimicrobial activity. Afr J Pharm Pharmacol. 2011;5(8):1150-1156.

28. Kebebew M, Mohamed E. Indigenous knowledge on use of medicinal plants by indigenous people of Lemo district, Hadiya zone, Southern Ethiopia. Int J Herbal Med. 2017;5(4):124-135.

29. Maryo M, Nemomissa S, Bekele T. An ethnobotanical study of medicinal plants of the Kembatta ethnic group in Enset-based agricultural landscape of Kembatta Tembaro (KT) Zone, Southern Ethiopia. Asian J Plant Sci Res. 2015;5(7):42-61.

30. Tuasha N, Petros B, Asfaw Z. Medicinal plants used by traditional healers to treat malignancies and other human ailments in Dalle District, Sidama Zone, Ethiopia. J Ethnobiol Ethnomed. 2018;14(1):15. doi:10.1186/s13002-018-0213-Z

31. Jirata MG. Forest in indigenous health care systems: perspective from ethno-medicine. J Environ Sci. 2017;1(2):107-114.

32. Mukazayire M, Allaeys V, Buc Calderon P, et al. Ethnobatanic study around volcanoes National Park of Rwanda. New York Sci J. 2010;3:37-49.

33. Okello S, Nyunja R, Netondo GW, Onyango JC. Ethnobotanical study of medicinal plants used by Sabaots of Mt. Elgon Kenya. African J Trad Complement Altern Med. 2010;7(1). doi:10.4314/ ajtcam.v7i1.57223

34. Sobrinho A, de Souza E, Fontenelle R. A review on antimicrobial potential of species of the genus Vernonia (Asteraceae). $J$ Med Plants Res. 2015;9(31):838-850. doi:10.5897/JMPR2015.5868

35. Muthaura C, Rukunga G, Chhabra S, Mungai G, Njagi E. Traditional phytotherapy of some remedies used in treatment of malaria in Meru district of Kenya. South African Journal of Botany. 2007;73(3):402-411. doi:10.1016/j.sajb.2007.03.004 
36. Muregi F, Chhabra S, Njagi E, et al. In vitro antiplasmodial activity of some plants used in Kisii, Kenya against malaria and their chloroquine potentiation effects. J Ethnopharmacol. 2003;84 (2-3):235-239. doi:10.1016/S0378-8741(02)00327-6

37. Meragiaw M, Asfaw Z. Review of antimalarial, pesticidal and repellent plants in the Ethiopian traditional herbal medicine. Res Rev. 2014;3(3):21-45.

38. Amuka O, Mulei J, Gatwiri B. A brief ethnbotanical survey of some medicinal plants used by the Kanjoo community in Meru. Adv Biotechnol Microbiol. 2017;5(1):555654.

39. Hamill F, Apio S, Mubiru N, et al. Traditional herbal drugs of southern Uganda. $J$ Ethnopharmacol. 2000;70(3):281-300. doi:10.1016/S0378-8741(00)00180-X

40. Toyang NJ, Verpoorte R. A review of the medicinal potentials of plants of the genus Vernonia (Asteraceae). J Ethnopharmacol. 2013;146(3):681-723.

41. Kiplimo JJ. A Review on the biological activity and the triterpenoids from the genus Vernonia (Asteraceae Family). International Research Journal of Pure and Applied Chemistry. 2016;11:1-14. doi:10.9734/IRJPAC/2016/25091

42. Woldeab B, Regassa R, Alemu T, Megersa M. Medicinal plants used for treatment of diarrhoeal related diseases in Ethiopia. Evid Based Complement Altern Med. 2018;2018:1-20. doi:10.1155/ 2018/4630371

43. Mengesha GG. Ethnobotanical survey of medicinal plants used in treating human and livestock health problems in Mandura Woreda of Benishangul Gumuz, Ethiopia. Adv Med Plant Res. 2016;4(1):11-26.

44. Giday M, Asfaw Z, Woldu Z. Medicinal plants of the Meinit ethnic group of Ethiopia: an ethnobotanical study. J Ethnopharmacol. 2009;124(3):513-521. doi:10.1016/j.jep.2009.05.009

45. Ruth L, Manani Solomon D. Ethnobotanical survey and propagation of some endangered medicinal plants from south Nandi district of Kenya. J Anim Plant Sci. 2010;8(3):1016-1043.

46. Odongo EA. An Ethnobotanical, Antioxidant and AntiInflammatory Study of Medicinal Plants Used in Kakamega County, Western Kenya. University Of Nairobi; 2016.

47. Bekele G, Reddy PR. Ethnobotanical study of medicinal plants used to treat human ailments by Guji Oromo tribes in Abaya District, Borana, Oromia, Ethiopia. Univ J Plant Sci. 2015;3 (1):4. doi:10.13189/ujps.2015.030101

48. Ragunathan M, Abay SM. Ethnomedicinal survey of folk drugs used in Bahirdar Zuria district, Northwestern Ethiopia. 2009.

49. Mesfin F, Demissew S, Teklehaymanot T. An ethnobotanical study of medicinal plants in Wonago Woreda, SNNPR, Ethiopia. $J$ Ethnobiol Ethnomed. 2009;5(1):28. doi:10.1186/1746-4269$5-28$

50. Focho D, Ndam W, Fonge B. Medicinal plants of Aguambu-Bamumbu in the Lebialem highlands, southwest province of Cameroon. African J Pharm Pharmacol. 2009;3(1):1-13.

51. Namukobe J, Kasenene JM, Kiremire BT, et al. Traditional plants used for medicinal purposes by local communities around the Northern sector of Kibale National Park, Uganda. $J \quad$ Ethnopharmacol. 2011;136(1):236-245. doi:10.1016/j. jep.2011.04.044

52. Tugume P, Kakudidi EK, Buyinza M, et al. Ethnobotanical survey of medicinal plant species used by communities around Mabira Central Forest Reserve, Uganda. J Ethnobiol Ethnomed. 2016;12 (1):5. doi:10.1186/s13002-015-0077-4

53. Megersa M, Asfaw Z, Kelbessa E, Beyene A, Woldeab B. An ethnobotanical study of medicinal plants in Wayu Tuka district, east Welega zone of Oromia regional state, West Ethiopia. J Ethnobiol Ethnomed. 2013;9(1):68. doi:10.1186/1746-4269-9-68

54. Tugume P, Nambejja C, Nyakoojo C, Kamatenesi-Mugisha M. Medicinal plant species used in the treatment of skin diseases in Katabi Subcounty, Wakiso District, Uganda. Ethnobot Res Appl. 2019;18:1-17. doi:10.32859/era.18.20.1-17
55. Tadesse M, Hunde D, Getachew Y. Survey of medicinal plants used to treat human diseases in Seka Chekorsa, Jimma Zone, Ethiopia. Ethiop J Health Sci. 2005;15(2).

56. Birhanu T, Abera D, Ejeta E, Nekemte E. Ethnobotanical study of medicinal plants in selected Horro Gudurru Woredas, Western Ethiopia. J Biol Agric Healthc. 2015;5(1):83-93.

57. Moshi MJ, Otieno DF, Weisheit A. Ethnomedicine of the Kagera Region, north western Tanzania. Part 3: plants used in traditional medicine in Kikuku village, Muleba District. $J$ Ethnobiol Ethnomed. 2012;8(1):14. doi:10.1186/1746-4269-8-14

58. Yigezu Y, Haile DB, Ayen WY. Ethnoveterinary medicines in four districts of Jimma zone, Ethiopia: cross sectional survey for plant species and mode of use. BMC Vet Res. 2014;10(1):76. doi:10.1186/1746-6148-10-76

59. Gemechu W, Meresa A, Teka F, Berhau T, Tadele A. An ethno botanical review on medicinal plants used for the management ectoparasitic skin diseases of ruminants. J Med Plants. 2019;7 (4):212-224.

60. Esubalew ST, Belete A, Lulekal E, Gabriel T, Engidawork E, Asres K. Review of ethnobotanical and ethnopharmacological evidences of some Ethiopian medicinal plants traditionally used for the treatment of cancer. Ethiop J Health Dev. 2017;31 (3):161-187.

61. Enyew A, Asfaw Z, Kelbessa E, Nagappan R. Status of medico-cultural commercial plants at Fiche town market, Ethiopia. Int J Pharm H Care Res. 2013;1(4):227-236.

62. Babu N, Temesgen OA. Phytochemical Investigation and Antimicrobial Activities of Extract of Vernonia Auriculifera Hiern Leaves. Haramaya University; 2015.

63. Orebo T. Isolation and characterization of leaves extract of Vernonia auriculifera. Int J Curr Res. 2019;11(9).

64. Sobrinho ACN, de Souza EB, Dos santos fontenelle RO. A review on antimicrobial potential of species of the genus Vernonia (Asteraceae). J Med Plants Res. 2015;9(31):838-850.

65. Hamill F, Apio S, Mubiru N, et al. Traditional herbal drugs of Southern Uganda, II: literature analysis and antimicrobial assays. $J$ Ethnopharmacol. 2003;84(1):57-78. doi:10.1016/S03788741(02)00289-1

66. Council NR. Guide for the Care and Use of Laboratory Animals. National Academies Press; 2010.

67. Tesfaye WH, Alamneh EA. In vivo antimalarial activity of the crude extract and solvent fractions of the leaves of Zehenria scabra (Cucurbitaceae) against Plasmodium berghei in mice. $J$ Med Plant Res. 2014;8(42):1230-1236.

68. Satyajit D, Sarker ZL, Alexander I. Natural Products IsolationSecond Edition. Biotechnology ${ }^{\mathrm{TM}}$. United Kingdom: Humana Press Inc; 2006.

69. Geleta B, Makonnen E, Debella A, Tadele A. In vivo antihypertensive and antihyperlipidemic effects of the crude extracts and fractions of Moringa stenopetala (Baker f.) Cufod. leaves in rats. Front Pharmacol. 2016;7:97. doi:10.3389/fphar.2016.00097

70. Anza M, Worku F, Libsu S, Mamo F, Endale M. Phytochemical screening and antibacterial activity of leaves extract of Bersama abyssinica. J Adv Bot Zool. 2015;3(2):1-5.

71. Megersa M, Asfaw Z, Kelbessa E, Beyene A, Woldeab B. An ethnobotanical study of medicinal plants in Wayu Tuka district, east Welega zone of Oromia regional state, West Ethiopia. $J$ Ethnobiol Ethnomed. 2013;9(1):1-18.

72. Trease G, Evans M. Text Book of Pharmacognosy 13th Edition Bailiere Tindall, London, Toronto. Tokyo: PGS; 1989:200-201.

73. Pandey A, Tripathi S. Concept of standardization, extraction and pre phytochemical screening strategies for herbal drug. J Pharmacogn Phytochem. 2014;2(5).

74. Tiwari P, Kumar B, Kaur M, Kaur G, Kaur H. Phytochemical screening and extraction: a review. Int Pharm Sci. 2011;1 (1):98-106. 
75. Demilew W, Adinew GM, Asrade S. Evaluation of the wound healing activity of the crude extract of leaves of Acanthus polystachyus delile (Acanthaceae). Evid Based Complement Altern Med. 2018;2018:1-9. doi:10.1155/2018/2047896

76. Langley CA, Belcher D. Pharmaceutical Compounding and Dispensing. Pharmaceutical Press; 2012.

77. Padhi L, Panda SK. Antibacterial activity of Eleutherine bulbosa against multidrug-resistant bacteria. J Acute Med. 2015;5 (3):53-61. doi:10.1016/j.jacme.2015.05.004

78. Bhaskar A, Nithya V. Evaluation of the wound-healing activity of Hibiscus rosa sinensis L (Malvaceae) in Wistar albino rats. Indian J Pharmacol. 2012;44(6):694. doi:10.4103/0253-7613.103252

79. Kebebew M, Mohamed HM. Indigenous knowledge on use of medicinal plants by indigenous people of Lemo district, Hadiya zone, Southern Ethiopia. Int J Herbal Med. 2017;5(4):124-135.

80. OECD. Guideline for testing of chemicals: draft updated test guideline 434 on acutedermal toxicity. Draft Guideline. 2015;1-12.

81. Beshir K, Shibeshi W, Ejigu A, Engidawork E. In-vivo wound healing activity of $70 \%$ ethanol leaf extract of Beciumgrandiflorum Lam.(Lamiaceae) in mice. Ethiop Pharm J. 2016;32:117-130. doi:10.4314/epj.v32i2.3

82. Draize WG, Calvery HO. Methods for the study of irritation and toxicity of substances applied topically to the skin and mucous membranes. J Pharmacol Exp Ther. 1944;82:377-390.

83. Kumar V, Khan AA, Nagarajan K. Animal models for the evaluation of wound healing activity. Int Bull Drug Res. 2013;3 (5):93-107.

84. Samanta R, Pattnaik AK, Pradhan KK, Mehta BK, Pattanayak SP, Banerjee S. Wound healing activity of silibinin in mice. Pharmacognosy Res. 2016;8(4):298. doi:10.4103/09748490.188880

85. Zeng $\mathrm{Q}$, Xie $\mathrm{H}$, Song $\mathrm{H}$, et al. In vivo wound healing activity of Abrus cantoniensis extract. Evid Based Complement Altern Med. 2016;2016:1-7. doi:10.1155/2016/6568528

86. Kumar SR, Vivek K, Saurabh K, Pavan Y, Amit R. Healing potential of gel containing extract of ougeinia oojeinensis on excision wounds in wistar rats. 2009.

87. Pastar I, Stojadinovic O, Yin NC, et al. Epithelialization in wound healing: a comprehensive review. Adv Wound Care. 2014;3 (7):445-464. doi:10.1089/wound.2013.0473

88. Subalakshmi M, Saranya A, Maheswari MU, Jarina A, Kaviman S. An overview of the current methodologies used for the evaluation of drugs having wound healing activity. Int $J$ Exp Pharmacol. 2014;4(2):127-131.

89. Armstrong DG, Jude EB. The role of matrix metalloproteinases in wound healing. J Am Podiatr Med Assoc. 2002;92(1):12-18. doi:10.7547/87507315-92-1-12

90. Jha RK, Bhandari A, Nema RK. Influence of flower head aqueous extract of Sphaeranthus indicus Linn. on wound healing in albino rats. Am Eur J Sci Res. 2011;6:13-18.

91. Bharat M, Verma DK, Shanbhag V, Rajput RS, Nayak D, Amuthan A. Ethanolic extract of oral Areca catechu promotes burn wound healing in rats. Int J Pharm Sci Rev Res. 2014;25 (2):145-148.

92. Arun M, Satish S, Anima P. Evaluation of wound healing, antioxidant and antimicrobial efficacy of Jasminum auriculatum Vahl. leaves. Avicenna J Phytomed. 2016;6(3):295.
93. Wosgrau ACC, da Silva Jeremias T, Leonardi DF, Pereima MJ, Di Giunta G, Trentin AG. Comparative experimental study of wound healing in mice: pelnac versus integra. PLoS One. 2015;10(3): e0120322. doi:10.1371/journal.pone.0120322

94. Leary SL, Underwood W, Anthony R, et al. AVMA Guidelines for the Euthanasia of Animals: 2013. Schaumburg, IL: American Veterinary Medical Association; 2013.

95. Murthy S, Shalini Goel MKG, Purohit V, Sharma H, Goel RK, Goel RK. Evaluation of in vivo wound healing activity of Bacopa monniera on different wound model in rats. Biomed Res Int. 2013;2013:1-9. doi:10.1155/2013/972028

96. Mulisa E, Asres K, Engidawork E. Evaluation of wound healing and anti-inflammatory activity of the rhizomes of Rumex abyssinicus J.(Polygonaceae) in mice. BMC Complement Altern Med. 2015;15(1):1-10.

97. Tuasha N, Petros B, Asfaw Z. Medicinal plants used by traditional healers to treat malignancies and other human ailments in Dalle District, Sidama Zone, Ethiopia. J Ethnobiol Ethnomed. 2018;14(1):1-21.

98. Kebebew M. Diversity, knowledge and use of medicinal plants in Abay Chomen district, Horo Guduru Wollega zone, Oromia region of Ethiopia. J Med Plants Res. 2017;11(31):480-500. doi:10.5897/JMPR2016.6274

99. Bitew H, Gebregergs H, Tuem KB, Yeshak MY. Ethiopian medicinal plants traditionally used for wound treatment: a systematic review. Ethiop J Health Dev. 2019;33(2).

100. Allen L, Ansel HC. Introduction to Pharmaceutical Dosage Forms. 4th ed. Philadelphia: Lea and Febiger; 1985.

101. De Villiers M. Ointment Bases. Pract Guide Contemp Pharm Pract. 2009;3:277-290.

102. Ghildiyal GM, Joshi VK, Goel RK, Goel R. Wound healing and antimicrobial activity of two classical formulations of Laghupanchamula in rats. $J$ Ayurveda Integrat Med. 2015;6 (4):241. doi:10.4103/0975-9476.157952

103. Stadelmann DA, Tobin GR, Tobin GR. Impediments to wound healing. Am J Surg. 1998;176:39S-47S. doi:10.1016/S00029610(98)00184-6

104. Agyare DA, Agyepong N, Boakye YD, Mensah KB, Ayande PG. Antimicrobial, antioxidant, and wound healing properties of Kigelia africana (Lam.) beneth. and Strophanthus hispidus DC. Adv Pharmacol Sci. 2013;2013:1-10. doi:10.1155/ 2013/692613

105. Albejo B, Endale M, Kibret B, Anza M. Phytochemical investigation and antimicrobial activity of leaves extract of Vernonia auriculifera Hiern. J Pharm Pharmacogn Res. 2015;3 (6):141-147.

106. Wolde BBT, Tiruha K, Hailemariam T, Tiruha K. Phytochemical analysis and antimicrobial activity of Hagenia Abyssinica. Indian J Pharm Pharmacol. 2016;3(3):127-134. doi:10.5958/23939087.2016.00028.5

107. MacDonald J. Global initiative for wound and lymphoedema care (GIWLC). J Lymphoedema. 2009;4(2):92-95.

108. Research IfLA. National Research Council: Guide for the Care and Use of Laboratory Animals. Washington DC: National Academy Press; 1996. 


\section{Publish your work in this journal}

The Journal of Experimental Pharmacology is an international, peerreviewed, open access journal publishing original research, reports, reviews and commentaries on all areas of laboratory and experimental pharmacology. The manuscript management system is completely online and includes a very quick and fair peer-review system. Visit http://www.dovepress.com/testimonials.php to read real quotes from published authors.

Submit your manuscript here: https://www.dovepress.com/journal-of-experimental-pharmacology-journal 